\title{
A Brief Analysis of College Students Using the Internet to Start Their Own Business
}

\author{
Li Dan \\ Associate professor \\ Liaoning Institute of Science and Technology \\ Benxi, Chain
}

\begin{abstract}
With the number of college graduates increasing and the number of social employment posts not increasing, the pressure on the job market is increasing. The impact on the employment of college graduates is inevitable, and the contradiction between the employment and the market is gradually emerging. And college students online entrepreneurship can partially solve the problem of difficult employment. The paper demonstrates the situation of college students' entrepreneurship in our country. The main emphas is placed is to reveal the significance and advantages for college students' entrepreneurship online. It is pointed out that it's the priority for college students to start business with the support from national policies and cultivation of colleges and universities. But the problems also exist in the network entrepreneurship of college students. The purpose of this paper is to offer some suggestions for college students to start business online. The best way to exercise one's ability is through practice. With the help of this practice platform, it is hoped to transform college students with entrepreneurial ideals into those who actually choose to start a business, and apply the practical experience accumulated in the school to their future work effectively. Because of the college student's self-employment, the development of the industry has been injected with new elements and added new impetus.
\end{abstract}

Keywords—college students' entrepreneurship, online, cultivate, concept

\section{INTRODUCTION}

Education has entered the "popular" stage in China. Since the enrollment expansion in 1999, the number of college graduates has gradually increased, and the number of college graduates nationwide reached 7.27 million in 2014. At the same time, the unemployed graduates in the last years also joined the competition for jobs. On the other hand, the rise in labor costs in recent years and the slowdown or even regression of global economic growth have led to the prudent selection by employers and reduced demand for labor. In this situation, the employment pressure of college graduates is increasing. A high degree of attention is given to the current situation by the state and society from all walks of life. In 2013 the general office of the state council released "Notice about for 2013 national ordinary institutions of higher learning graduates employment". And "How to solve the problem of employment of college graduates", "Strengthen the employment of university graduates and guide service" and "Encourage college graduates self-employment were the key words in the speech.[1]

\section{CURRENT STATUS OF ONLINE ENTREPRENEURSHIP FOR COLLEGE STUDENTS}

\section{A. The popularity of the Internet has made online entrepreneurship possible}

Today, the Internet has become an integral part of people's lives. With the popularization of the Internet and the improvement of people's living standards, modern online tools such as computers and mobile phones gradually invade people's lives. For college students, the Internet is an important part of their life and study, directly affecting and changing their lives.

\section{B. The change in people's concept of consumption brings opportunities for online entrepreneurship}

With the progress of the society, people have higher and higher requirements on the quality of life. Merchants seize the demand of mass consumption and use mobile Internet and other tools to publicize, and online entrepreneurship comes into being naturally. In addition, the changes of people's concept of employment and the enhancement of selfemployment awareness have greatly promoted the rapid development of Internet entrepreneurship. Secondly, the change of people's consumption concept also promotes the rapid transformation of the market to demand guiding, and the Internet greatly satisfies this requirement. The ready-made employment opportunities provided by the society for college students are ultimately limited. College students should change their minds and understand that self-employment is a new way of employment in the process of employment. College students' interest in the Internet is combined with their career development. They use the Internet to strengthen professional practice and lay the foundation for their future. At present; the development of network economy shows us its vitality. It is an important part of market economy. Network market is infinite and network consumption demand is ceaseless growth. For college students, they can start their own business with the network they know well, without time and space, with limited capital and low risk. They can manage themselves, learn and grow in actual combat, and constantly explore, and transform actual experience into productivity. Therefore, the development of network economy brings both challenges and valuable opportunities to college students' entrepreneurship. 


\section{The diversity of people's spending habits makes online entrepreneurship necessary}

People began to pursue an efficient, convenient and costeffective standard of living, and the diversification of people's consumption habits also gave rise to many industries in urgent need of development. With the advancement of Internet application technology, more and more people made money on it and commercialized it. College students' selfemployment is a way to relieve employment pressure. The state and local governments have introduced various preferential measures to encourage college students to use the Internet to start their own businesses and realize their entrepreneurial dreams. Using Internet marketing to start a business can help college students entrepreneurs to avoid their weaknesses and solve a series of problems. Relevant data show that in 2008, the number of Chinese people who used the Internet to solve the employment pressure reached 570,000, providing new employment direction for college students

\section{Youth is another characteristic of Internet entrepreneurship}

Many college students start their own businesses to realize their own value and improve their initiative. Unlike brick-andmortar startups, Internet startups have lower barriers to entry, and the environment is getting more relaxed. More and more college students are joining the entrepreneurial trend. They don't necessarily have computer expertise, they may not always be top achievers in school, but they all know how to use Internet technology. Different fields such as e-commerce, communication, mailbox, music and military reflect the diversity of Internet entrepreneurship, among which online store setting accounts for a large proportion. With the encouragement of the state, the online startup education gradually formed. In addition, the geographical distribution of Internet entrepreneurship is unbalanced, mainly concentrated in the eastern coastal developed regions, while the western regions such as Gansu, Shaanxi, Guizhou and Tibet are less.

\section{THE SIGNIFICANCE OF SELF-ENTREPRENEURSHIP ON THE NETWORK OF UNIVERSITY STUDENTS}

College students' self-employment refers to those who have the conditions of employment give up the employment opportunity to establish industry and solve their employment problems by relying on their own capital and social resources. For example; network marketing is a kind of marketing activity based on the Internet. It is an integral part of an enterprise's overall marketing strategy and cannot be separated from the marketing environment. The purpose of network marketing is not only to promote online marketing, but also to promote online marketing and increase customer loyalty. It has many advantages, such as quick market share, individualization and low cost.[2]

\section{A. Combine theory with practice and apply what they have learned}

According to statistics, the current education model in Chinese universities is mainly based on theoretical knowledge, and students lack practical ability and innovative spirit, which is seriously out of line with the actual demand of market labor force. At present, there are many problems in the e-business teaching in China, such as the weak operational ability of students, the lack of innovation consciousness and ability, the lack of practical teaching projects, the theoretical hole, and the rapid pace of development of e-business. To fundamentally solve these problems, the only way is to strengthen students' practical teaching so that students can truly apply book knowledge to practice, and cultivate students' entrepreneurial spirit. The online store which is set up on the operating ecommerce platform is a kind of online entrepreneurship. All the practical links are real, and the problems encountered by students are also complex and diversified. How to solve the problems encountered, it is difficult to find ready-made answers in books, and students need to keep exploring and flexible in practice.

\section{B. Cultivate students' entrepreneurial practice ability}

Through the practice of online entrepreneurship practice, students can master the basic skills and requirements of online entrepreneurship, accumulate the knowledge and experience of online entrepreneurship, eliminate the fear of entrepreneurship, and establish the confidence of entrepreneurship. For instance, online store does not need too much capital input, can be in the case of the order to restock goods. At the same time, online stores are free to change their varieties at any time, or to switch to other businesses. Online store opening can be carried out in ordinary computer laboratory, which does not need to rent a store alone, is not subject to store space restrictions, and is not subject to geographical location. Students can make full use of their spare time, group, take turns on duty, answer customers' questions online, and conduct online commodity publicity and promotion.

\section{Master the most advanced technology and management ideas}

E-commerce itself is a comprehensive product of modern technology and management. The implementation and operation of e-commerce is a complete process and an interactive process including commodity flow, information flow, capital flow and logistics. The practice on the ecommerce website revolves around each link of e-commerce and completes the whole process in one breath. Therefore, through online entrepreneurship practice, students can master the latest technology and the most advanced management ideas. Through the training of the teaching link of entrepreneurship practice on the e-commerce website, it is more about providing students with pre-employment training and increasing their employment opportunities. [3]

\section{THE ADVANTAGES OF COLLEGE STUDENTS' ONLINE MARKETING AND ENTREPRENEURSHIP}

\section{A. Network popularization and convenient communication}

According to the 33rd statistical report on China's Internet development, the number of Chinese Internet users reached 6 as of December 2013.Of the 1.8 billion, 500 million are mobile phone users, and the Internet penetration rate is 45.8\%.Network marketing contains a large amount of information, covers a large area, and is not limited by space and time. The development of network marketing makes consumers' demands more personalized and differentiated. 
The biggest advantage of self-employment through network marketing is that it can more timely realize direct communication with customers, accurately understand who the customers are and what their needs are, create value for each customer while reflecting its own value, and achieve a "win-win" situation.[4]

\section{B. Online sales platform has been formed}

China's e-commerce has initially formed a network transaction system with Chinese characteristics, the situation of plat forming has also been formed, and various network services have been preliminarily improved. The launch of "yu 'ebao", the listing of Alibaba, the appearance of Meituan, Ele. me and other platforms all indicate that e-commerce has developed to a new height

\section{Simplicity of sales}

The online marketing activities not only save the time of transmission process, but also reduce the cost of intermediate links, speed up the flow of products, and reduce the cost of buying and selling to the greatest extent. Internet marketing enables two-way flow of information by sending emails, setting up BBS, setting up virtual communities, and so on. Consumers also have more choices.

\section{Professional knowledge and interests of college students}

College students belong to the unique group in the entrepreneurial team. They are often full of vitality, have a certain level of knowledge and innovation ability, and dare to put their own ideas into practice. With the rapid development of the Internet and mobile terminals, users tend to be younger. When college students choose to start a business, the obvious advantages of online market and marketing mode can be more accepted and utilized by them.

\section{E. Support from national policies and cultivation of colleges and universities}

A new trend of "double innovation" is emerging all over the country. As the front of education, the "double creation" activity of colleges and universities in response to the central call is also in full swing in the country's colleges and universities spreading. For this reason, the ministry of education successively issued documents such as "Opinions on vigorously promoting innovation and entrepreneurship in colleges and universities" and "Opinions on self-employment of college students", aiming to encourage college students to actively participate in entrepreneurial activities in the face of the severe employment market.

\section{PROBLEMS EXISTING IN THE NETWORK ENTREPRENEURSHIP OF COLLEGE STUDENTS}

\section{A. Low success rate}

The success rate of college students' Internet entrepreneurship is low, accounting for only about $2 \%$.Every year, a large number of graduates choose to start businesses on the Internet, but only a few succeed. The fierce competition is one of the reasons, but more importantly, college students generally have a superior outlook, lack of work experience, poor interpersonal relationship and psychological quality, and gradually give up under the conditions of low income and tired work.

\section{B. The lack of education and law}

Education of colleges and universities is relatively shallow in terms of students' self-employment, and some developed regions have offered relevant courses. However, in general trend, education of colleges and universities still has a great lag. In particular, progress on the training of practical talents and innovation consciousness is slow.

\section{Traditional concepts from parents}

People are old-fashioned and prefer to stay in the present situation rather than do something risky. After the reform and opening up, the western ideological trend collided with the traditional culture and achieved some results, but the whole social environment still has some restrictions on entrepreneurship. Parents also want their children to have an iron rice bowl, and it's easy to object when the venture fails.

\section{The chaos of the network}

Although the state gives a high degree of support, relevant policies need to be further improved. As a result of virtual transaction, credit risk is very large. Criminals can easily use network vulnerabilities to commit fraud. It's easy to expose personal information, resulting in serious losses. At the same time, network entrepreneurship needs to be linked with logistics, which is too expensive.

\section{E. Technical problems of online entrepreneurship}

The choice of the online platform on which the online store is set up, the function, service, operation mode and management level of different online store platforms are quite different. The problems of the construction of online stores must be considered. The general professional online store platform has rich functions and simple operation interface, and the construction of online stores can be completed through the template operation. The issue of online store promotion also needs consideration. Such online stores built on third-party e-commerce platforms are very different from the promotion of general traditional stores. The supply of goods for starting a business online needs consideration too. It had better be to open characteristic shop. Payment security management issues also need consideration. Trading requires minimized risk.[5]

\section{SUGGESTIONS FOR COLLEGE STUDENTS TO START A BUSINESS ONLINE}

\section{A. Improve the quality and capacity of online store}

Reputation matters. In terms of product quality and service quality, if there are high-quality goods, reasonable prices and good services, the number of fixed customers in the store will increase, and the customers will also play a role in publicity. The more the customers, the more the turnover will increase. Therefore, the business should always note quality of the products and service quality, striving to improve their credibility. 


\section{B. Choose high-tech products or intellectual services}

College students are at the forefront of high technology, receiving modern education and mastering advanced scientific and technological knowledge and skills. They have advantages in this field, and they can consider putting their talents into practice in the fields of software development, webpage making, network service and game, so as to carry out innovation and entrepreneurship or they can select smart service areas and select areas that they are familiar with or interested in.

\section{Do market research}

Before starting a business, they must have a good understanding of the market and need to do research, business plan. Meanwhile, they need to make a good prediction of the competitive risk and financial risk.

\section{CONCLUSION}

The best way to exercise one's ability is through practice. In the past, in the education model of college students, only the existing knowledge and experience are taught, but the creative potential is neglected. In the education goal, emphasis should be placed on cultivating graduates who are "fit" for various industries, while neglecting to cultivate college students who can "start their own businesses" in society. With the help of this practice platform, we hope to transform college students with entrepreneurial ideals into those who actually choose to start a business, and apply the practical experience accumulated in the school to their future work effectively. The subjectivity principle of entrepreneurial education requires respecting the development of students' personalities. In the process of entrepreneurial values education, teaching should be combined with the cases of success or failure in the society. We should respect the psychological needs of college students to seek new and different things, and guide students to actively participate in entrepreneurial education to realize self-value. Because of the college student's self-employment, the development of the industry has been injected with new elements and added new impetus. As the main position of China's entrepreneurial education system, university entrepreneurial education will inevitably usher in new changes and opportunities, and prompt us to treat university entrepreneurship education with a new perspective and way of thinking.

\section{ACKNOWLEDGMENT}

"Internet + Poverty Alleviation - a Link to Love in the Sun Huanren county Wan Longbei village farmers poverty alleviation idea." College Students' Innovation and Entrepreneurship Project of Liaoning Province in 2018(20181140056)

\section{REFERENCES}

[1] Liu Jingyu, "Research on college students' online entrepreneurship and innovation" [J] Youth and Society 2015, 616

[2] Ji Shaobin, "An empirical study of cross-border e-commerce entrepreneurship of college students"[J] Business and Trade Talent 2016, 187

[3] Shao xiong; "Problems and Suggestions of college students using Internet marketing to start their own business" [J]. Social Develop

[4] Cheng Yanlin "Perplexity and countermeasures of college students' online entrepreneurship" [J]Youth studies in China, 2007, 11

[5] Zhu Jing "An analysis of college students 'entrepreneurship in campus ecommerce environment" [J] Market Marketing, 2016 ,546 